\title{
Analisis Pelaksanaan Program Pelatihan dan Pengembangan Karyawan: Studi Kasus Pada PT Visi Sukses Bersama Jakarta
}

\author{
R. Ati Haryati \\ Universitas Bina Sarana Informatika /Administrasi Perkantoran \\ e-mail: r.ati.rah@bsi.ac.id
}

\begin{abstract}
Cara Sitasi: Haryati, R. A. (2019). Analisis Pelaksanaan Program Pelatihan dan Pengembangan Karyawan: Studi Kasus Pada PT Visi Sukses Bersama Jakarta. Widya Cipta, 3(1), 91-98.
\end{abstract}

\begin{abstract}
The importance of employee training and development programs is a necessity for companies that want to improve the capabilities, knowledge and experience of employees in the company. The problems that arise in training and development carried out by the company are often not in accordance with the needs of the company, and individual assignments so as not to support the work performance and career of employees. PT Visi Sukses Bersama works to improve employee productivity by conducting employee training and development programs for 3 (three) months, the goal is that employees who have been selected in the recruitment and selection stages carry out their duties well and reduce errors or gaps in the knowledge held by employees. The method used in this study is a qualitative descriptive data collection method, namely observation, interview and literature study. The results of this research indicate that there is a series of procedures from determining participant criteria, determining needs, selecting methods, making decisions and making evaluations of the implementation of training and employee performance collaborated in the Kirkpatrick Evaluation Model. The results of this study were also supported by an analysis of the obstacles encountered in the training program and the following development solutions.
\end{abstract}

Keywords: Training, Development, Case Study

\section{PENDAHULUAN}

Sumber daya manusia merupakan elemen utama organisasi dibandingkan dengan elemen lain seperti modal, teknologi, dan uang, sebab manusia itu sendiri yang mengendalikan. Membicarakan sumberdaya manusia tidak terlepas dari kegiatan-kegiatan atau proses managemen lainnya seperti strategi perencanaan, pengembangan managemen dan pengembangan organisasi.

Pentingnya program Pelatihan dan pengembangan menjadi sebuah kebutuhan bagi perusahaan yang ingin meningkatkan kemampuan, pengetahuan, dan pengalaman karyawannya di perusahaan. Setelah karyawan diterima melalui proses rekrutmen dan seleksi, karyawan akan ditempatkan pada posisi dan jabatan yang ditentukan. Seringkali terjadi pada karyawan baru bahwa kemampuan dan keterampilan yang mereka miliki belum sesuai dengan yang diharapkan oleh perusahaan sehingga biasanya perusahaan harus melakukan program pelatihan dan pengembangan untuk mereka tidak terkecuali pada PT Visi Sukses Bersama.

Persoalan yang timbul dalam pelatihan dan pengembangan yang dilakukan oleh perusahaan seringkali belum sesuai dengan kebutuhan perusahaan, tugas, dan individu sehingga tidak mendukung prestasi kerja dan karir karyawan.

PT Visi Sukses bersama berupaya untuk meningkatkan prestasi dan produktivitas kerja karyawan dengan melakukan program pelatihan dan pengembangan yang bertujuan untuk mengurangi kesalahan atau kesenjangan pengetahuan yang dimiliki karyawan. Hambatan yang terjadi saat melakukan pelatihan dan pengembangan yang diberikan belum maksimal, Hal ini dapat dilihat dari karyawan mengalami kesulitan dalam memahami materi pelatihan dan pengembangan yang diberikan.

Oleh karena itu untuk meningkatkan kemampuan tenaga kerja, perusahaan harus menonjolkan usaha untuk mengembangkan kemampuan tenaga kerjanya. Tujuan dari pelatihan dan pengembangan adalah untuk memperbaiki produktivitas tenaga kerja dalam mencapai hasil yang telah ditetapkan oleh perusahaan.

Penelitian ini menjadi menarik karena tidak hanya menganalisis prosedur pelatihan dan karyawan untuk karyawan saja namun juga mengkaji evaluasi dan kendala dalam pelaksanaan pelatihan dan 
pengembangan karyawan dalam memberikan kontribusi terhadap performa perusahaan.

\section{Pelatihan}

Menurut Kaswan dalam (Massie, Tewal, \& Sendow, 2015) mendefinisikan "Pelatihan adalah proses meningkatkan pengetahuan, dan keterampilan karyawan. Pelatihan meliputi pengubahan sikap sehingga karyawan dapat melakukan pekerjaannya lebih efektif".

Menurut Handoko (Lolowang, Adolfina, \& Lumintang, 2016) "Pelatihan adalah proses meningkatkan pengetahuan dan keterampilan karyawan. Pelatihan mungkin juga meliputi pengubahan sikap sehingga karyawan dapat melakukan pekerjaannya lebih efektif. Pelatihan bisa dilakukan pada semua tingkat dalam organisasi. Pada tingkat bawah/ rendah pelatihan berisikan pengajaran bagaimana mengerjakan suatu tugas misalnya mengoperasikan mesin."

Gomes dalam jurnalnya (Onibala, Tewal, \& Sendow, 2017) menuturkan "Pelatihan adalah setiap usaha untuk memperbaiki performasi pekerjaan pada suatu pekerjaan tertentu yang sedang menjadi tanggung jawabnya, atau satu pekerjaan yang ada kaitannya dengan pekerjaanya.”.

Pada jurnalnya (Andayani \& Makian, 2016), Dessler mendefinisikan "Pelatihan adalah Proses mengajarkan karyawan baru atau yang ada sekarang, keterampilan dasar yang mereka butuhkan untuk menjalankan pekerjaan mereka"'.

Berdasarkan beberapa pengertian diatas, pelatihan adalah sebuah proses untuk meningkatkan kompetensi karyawan dan dapat melatih kemampuan, keterampilan, keahlian dan pengetahuan karyawan guna melaksanakan pekerjaan secara efektifitas dan efesien untuk mencapai tujuan disuatu perusahaan.

Terdapat tujuh tujuan utama program pelatihan yang dikemukakan oleh Simamora (2015:276), antara lain:

1. Memperbaiki kinerja Karyawan

Karyawan-karyawan yang bekerja secara tidak memuaskan karena kekurangan keterampilan merupakan calon utama pelatihan.

2. Memutakhirkan keahlian para karyawan sejalan dengan kemajuan teknologi.

Melalui pelatihan pelatih (trainer) memastikan bahwa karyawan dapat mengaplikasikan teknologi baru secara efektif.

3. Mengurangi waktu pembelajaran bagi karyawan baru agar kompeten dalam pekerjaan.

Karyawan baru seringkali tidak menguasai keahlian dan kemampuan yang dibutuhkan untuk menjadi "job competent" yaitu mampu mencapai output dan standard mutu yang diharapkan.
4. Membantu memecahkan masalah operasional Para Manager harus mencapai tujuan mereka dengan kelangkaan dan kelimpahan sumber daya

5. Mempersiapkan karyawan untuk promosi.

Salah satu cara untuk menarik, menahan, dan memotivasi karyawan melalui program pengembangan karier yang sistematik.

6. Mengorientasikan karyawan terhadap organisasi. Selama beberapa hari pertama di pekerjaan karyawan baru membentuk kesan pertama mereka terhadap organisasi dan tim manajemen.

7. Memenuhi kebutuhan pertumbuhan pribadi.

Pelatihan dan pengembangan dapat memainkan peran ganda dengan menyediakan aktivitasaktivitas yang menghasilkan efektivitas organisasional yang lebih besar dan meningkatkan pertumbuhan pribadi bagi semua karyawan.

Manfaat pelatihan menurut Simamora (2015:278), adalah:

1. Meningkatkan kuantitas dan kualitas produktivitas.

2. Mengurangi waktu belajar yang di perlukan karyawan untuk mencapai standar kinerja yang dapat diterima.

3. Membentuk sikap, loyalitas, dan kerja sama yang lebih menguntungkan.

4. Memenuhi kebutuhan perencanaan sumber daya manusia.

5. Mengurangi frekuensi dan biaya kecelakaan kerja.

6. Membantu karyawan dalam peningkatan dan pengembangan pribadi mereka.

Simamora (2015:278), menuliskan beberapa jenis pelatihan yaitu:

1. Pelatihan keahlian (skill training)

Merupakan pelatihan yang sering dijumpai di dalam organisasi. Program pelatihannya relatif sederhana: kebutuhan atau kekurangan di identifikasi melalui penilaian yang jeli, kriteria penilaian efektivitas pelatihan juga berdasarkan pada sasaran yang di identifikasikan pada penilaian.

2. Pelatihan ulang (re-training)

Pelatihan ulang berupaya memberikan kepada karyawan keahlian-keahlian yang mereka butuhkan untuk menghadapi tuntutan kerja yang berubah-ubah.

3. Pelatihan lintas fungsional (croos functional training)

Pelatihan karyawan untuk melakukan aktivitas kerja dalam bidang lainnya, selain dari pekerjaan yang ditugaskan.

4. Pelatihan tim

Tim manajemen, tim riset dan satuan tugas temporer merupakan karakteristik yang lazim di banyak organisasi, tim adalah sekolompok 
individu yang bekerja sama demi tujuan bersama.

5. Pelatihan kreativitas (creativity training)

Salah satu rancangan yang lazim diterapkan adalah brainstorming dimana para partisipan diberikan peluang untuk mengeluarkan gagasan sebebas mungkin.

Metode pelatihan harus berdasarkan kepada kebutuhan pekerjaan tergantung pada berbagai faktor, yaitu waktu, biaya, jumlah peserta, tingkat pendidikan dasar peserta, latar belakang peserta, dan lain-lain.

\section{On The Job}

Para peserta latihan langsung bekerja di tempat untuk belajar dan meniru suatu pekerjaan dibawah bimbingan seorang pengawas. Metode pelatihan dibedakan dalam 2 cara:

a. Cara informasi yaitu pelatih menyuruh peserta latihan untuk memperhatikan orang lain yang sedang melakukan pekerjaan, kemudian ia diperintahkan untuk mempraktekkannya.

b. Cara formal yaitu supervisor menunjuk seorang karyawan senior untuk melakukan pekerjaan tersebut, selanjutnya para peserta pelatihan melakukan pekerjaan sesuai dengan cara-cara yang dilakukan karyawan senior.

On the job dapat pula latihan dilakukan dengan menggunakan bagan, gambar, pedoman, contoh yang sederhana, demonstrasi, dan lain-lain. Kebaikan cara on the job ini ialah para peserta belajar langsung pada kenyataan pekerjaan dan peralatan. Adapun keburukannya adalah pelaksanaan sering tidak teratur (tidak sistematis) dan kurang efektif jika pengawas kurang pengalaman.

\section{Vestibule}

Vestibule adalah metode latihan yang dilakukan dalam kelas atau bengkel yang biasanya diselenggarakan dalam suatu perusahaan industri untuk memperkenalkan pekerjaan kepada karyawan baru dan melatih mereka mengerjakan pekerjaan tersebut. Melalui percobaan dibuat suatu duplikasi dari bahan, alat-alat, dan kondisi yang akan mereka tertentu dalam situasi kerja yang sebenarnya.

\section{Demonstration and Example}

Demonstration and example adalah metode latihan yang dilakukan dengan cara peragaan dan penjelasan bagaimana cara-cara mengerjakan sesuatu pekerjaan melalui contoh-contoh atau percobaan yang di demonstrasikan.

Demonstrasi merupakan metode latihan yang sangat efektif karena peserta melihat sendiri teknik mengerjakannya dan diberikan penjelasan-penjelasannya, bahkan jika perlu boleh dicoba mempraktekkannya.

\section{Simulation}

Simulation merupakan situasi atau kejadian yang ditampilkan semirip mungkin dengan situasi yang sebenarnya tapi hanya merupakan tiruan saja. Simulasi merupakan suatu teknik untuk mencontoh semirip mungkin terhadap konsep sebenarnya dari pekerjaan yang akan dijumpainya.

\section{Apprenticeship}

Metode ini adalah suatu cara untuk mengembangkan keahlian pertukangan sehingga para karyawan yang bersangkutan dapat mempelajari segala aspek dari pekerjaannya.

\section{Classroom Methods}

Metode pertemuan dalam kelas lecture (pengajaran), conference (rapat), programmed instruction, metode studi kasus, role playing, metode diskusi, dan metode seminar.

\section{Pengembangan}

Berbicara masalah pengembangan sumber daya manusia, sebenarnya dilihat dari dua aspek, yaitu kuantitas dan kualitas.

Siagian dalam (Wicaksono, 2016) mengartikan "Pengembangan (development) berbeda pengertiannya dengan pelatihan (training). Pengertian ini menekankan bahwa pengembangan meru-pakan suatu proses pendidikan jangka panjang bagi para karyawan manajerial untuk mempe-roleh penguasaan konsep-konsep abstrak dan teoritis secara sistematis.".

Menurut Armstrong dalam (Lolowang et al., 2016) "Pengembangan sumber daya manusia berkaitan dengan tersedianya kesempatan dan pengembangan belajar, membuat program-program training yang meliputi perencanaan, penyelenggaraan, dan evaluasi atas program-program tersebut".

Marwansyah (2016:155) mendefinisikan "Pengembangan adalah pelaksaan setiap aktivitas yang mengarah pada pembelajaran berkesinambungan dan pengembangan diri dan yang berkontribusi mewujudkan tujuan-tujuan individu dan organisasi".

Menurut Lee dan Bruvord dalam (Kurniawan, 2012), Pengembangan sumber daya manusia memiliki peran yang vital dalam upaya mengarahkan, mendorong, memotivasi peningkatan/pengembangan kemampuan dan keterampilan para karyawan yang diimplementasikan pada pekerjaannya untuk 
mencapai keefektifan sumber daya manusia dalam organisasi."

Menurut Martoyo dalam (Massie et al., 2015) mendefinisikan "pengembangan karier merupakan suatu kondisi yang menunjukkan adanya sebuah peningkatan-peningkatan status seseorang pada suatu organisasi dalam jalur karier yang telah ditetapkan dalam organisasi yang bersangkutan".

Dari beberapa pengertian diatas, dapat disimpulkan bahwa pengembangan adalah suatu proses perencanaan pembelajaran atau pengelolaan karyawan untuk mencapai hasil kerja yang optimal.

Menurut Hasibuan (2016:70), tujuan pengembangan hakikatnya menyangkut hal-hal berikut:

1. Produktivitas Kerja

Dengan pengembangan, produktivitas kerja karyawan akan meningkatkan kualitas dan kuantitas produksi semakin baik, karena technical skill, human skill, dan manajerial skill karyawan yang semakin baik.

2. Efisiensi

Pengembangan karyawan bertujuan untuk meningkatkan efisiensi tenaga, waktu, bahan baku, dan mengurangi daya mesin-mesin.

3. Kerusakan

Pengembangan karyawan bertujuan untuk mengurangi kerusakan barang, produksi, dan barang-barang mesin karena karyawan semakin ahli dan terampil dalam melaksanakan pekerjaannya.

4. Kecelakaan

Pengembangan bertujuan untuk mengurangi tingkat kecelakaan karyawan, sehingga jumlah biaya pengobatan yang dikeluarkan perusahaan berkurang.

5. Pelayanan

Pengembangan bertujuan untuk meningkatkan pelayanan yang lebih baik dari karyawan kepada nasabah perusahaan. Karena pemberian pelayanan yang baik merupakan daya penarik yang sangat penting bagi rekanan-rekanan perusahaan bersangkutan.

6. Moral

Dengan pengembangan, moral karyawan akan lebih baik karena keahlian dan keterampilannya sesuai dengan pekerjaannya sehingga mereka antusias untuk menyelesaikan pekerjaannya dengan baik.

7. Karier

Dengan pengembangan, kesempatan untuk meningkatkan karier karyawan semakin besar, karena keahlian, keterampilan, dan prestasi kerjanya lebih baik. Promosi ilmiah biasanya didasarkan kepada keahlian dan prestasi kerja seseorang.

8. Konseptual
Dengan pengembangan, manager semakin cakap dan cepat dalam mengambil keputusan yang lebih baik, karena technical skill, human skill, dan managerial skill-nya lebih baik.

9. Kepemimpinan

Dengan pengembangan, kepemimpinan seorang managerakan lebih baik human relations-nya lebih luwes, motivasinya lebih terarah sehingga pembinaan kerja sama vertical dan horizontal semakin harmonis.

10. Balas Jasa

Dengan pengembangan, balas jasa, (gaji, upah insentif, dan benefits) karyawan akan meningkat karena prestasi kerja mereka semakin besar.

11. Konsumen

Pengembangan karyawan akan memberikan manfaat yang baik bagi masyarakat konsumen karena mereka akan memperoleh barang atau pelayanan yang lebih bermutu.

Menurut Hasibuan (2016:85), kendala pengembangan yang dilakukan pasti selalu ada dan kita harus berusaha memenuhi pengaruh kendalakendala tersebut. Kendala-kendala pengembangan akan menghambat lancarnya pelaksanaan latihan dan pendidikan, sehingga sasaran yang tercapai kurang memuaskan

1. Peserta

Peserta pengembangan mempunyai latar belakang yang tidak sama atau heterogen, seperti pendidikan dasarnya, pengalaman kerjanya, dan usianya. hal ini akan menyulitkan dan menghambat kelancaran pelaksanaan latihan dan pendidikan karena daya tangkap, persepsi, dan daya nalar, mereka terhadap pelajaran yang diberikan berbeda.

2. Pelatih atau Instruktur

Pelatih atau instruktur yang ahli dan menstranfer pengetahuannya. Kepada para peserta latihan dan pendidikan sulit didapat. Akibatnya, sasaran yang diinginkan tidak tercapai.

3. Fasilitas Pengembangan

Fasilitas sarana dan sarana pengembangan yang dibutuhkan untuk latihan dan pendidikan sangat kurang atau tidak baik. Misalnya, buku-buku, alat-alat, dan mesin-mesin, yang akan digunakan untuk praktek kurang atau tidak ada. Hal ini akan menyulitkan dan menghambat lancarnya pengembangan.

4. Kurikulum

Kurikulum yang ditetapkan dan diajarkan kurang serasi atau menyimpang serta tidak sistematis untuk mendukung sasaran yang diinginkan oleh pekerjaan atau jabatan peserta bersangkutan. Untuk menetapkan kurikulum dan waktu mengajarkanya yang tepat sangat sulit.

5. Dana Pengembangan

Dana yang tersedia untuk pengembangan sangat terbatas, sehingga sering dilakukan secara 
terpaksa, bahkan pelatih maupun sarananya kurang memenuhi persyaratan yang dibutuhkan.

\section{METODOLOGI PENELITIAN}

Penelitian ini menggunakan metode kualitatif, yaitu metode untuk menyelidiki obyek yang tidak dapat diukur dengan angka-angka ataupun ukuran lain yang bersifat eksak. Penelitian kualitatif juga bisa diartikan sebagai riset yang bersifat deskriptif dan cenderung menggunakan analisis dengan pendekatan induktif. Tujuan menggunakan pendekatan kualitatif adalah agar peneliti dapat menggambarkan praktek nyata di balik fenomena yang terjadi terkait dengan pelaksanaan pelatihan dan pengembangan di PT Visi Sukses Bersama Jakarta. Data pada penelitian ini menggunakan data periode bulan AgustusNovember 2017. Metode pengumpulan data yang peneliti gunakan meliputi:

1. Observasi

Observasi adalah salah satu metode pengumpulan data dengan cara pengamatan langsung pada obyek penelitian. Tujuan menggunakan metode ini untuk mencatat seluruh pelaksanaan program pelatihan dan pengembangan karyawan PT Visi Sukses Bersama Jakarta.

2. Wawancara

Wawancara adalah metode pengumpulan data dengan membuat daftar pertanyaan terkait dengan obyek penelitian. Wawancara dilakukan dengan Supervisor Seleksi di PT Visi Sukses Bersama.

3. Dokumentasi

Dokumentasi merupakan salah satu metode pengumpulan data dari arsip, dokumen, peraturan perusahaan, buku dan sumber referensi lainnya yang mendukung riset ini.

\section{HASIL DAN PEMBAHASAN}

Pelatihan dan pengembangan karyawan pada PT Visi Sukses Bersama dilakukan selama 3 (tiga) bulan, tujuannya adalah agar karyawan yang telah terpilih dalam tahap rekrutmen dan seleksi dapat mengerti dan dapat melaksanakan tugas-tugasnya dengan baik dan benar serta karyawan lama supaya memiliki motivasi dalam bekerja. Berikut Prosedur Pelatihan dan Pengembangan Karyawan:

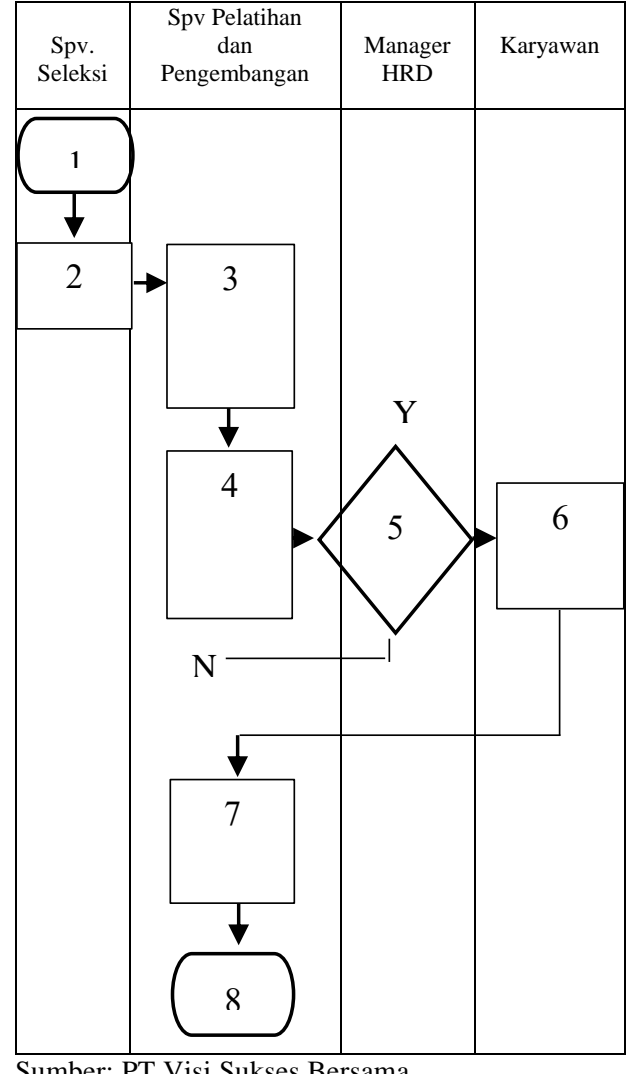

Gambar 1. Prosedur Pelatihan \& Pengembangan

Berdasarkan gambar 1 di atas, prosedur pelatihan dan pengembangan karyawan pada PT Visi Sukses Bersama, adalah:

1. Mulai dengan identifikasi data calon peserta

2. Karyawan

Supervisor Bagian Seleksi menyeleksi karyawan yang akan dipilih sebagai calon peserta pelatihan dan pengembangan. Bagi karyawan baru akan diberi pelatihan, sedangkan karyawan lama yang akan mendapat pengembangan dengan program yang disesuaikan karakteristik karyawan tersebut.

3. Identifikasi Kebutuhan Pelatihan dan Pengembangan

Pada Tahap ini, supervisor Pelatihan dan Pengembangan menganalisis kebutuhan pelatihan dan pengembangan yang disesuaikan dengan kompetensi karyawan serta mengidentifikasi tujuan dan kriteria pelatihan. Seperti kemampuan apa yang diperlukan karyawan dalam rangka menunjang kebutuhan organisasi.

4. Penyusunan Program Pelatihan dan pengembangan

Setelah melakukan penilaian, selanjutnya menyusun program pelatihan dan pengembangan yang terdiri dari metode pelatihan dan 
pengembangan. PT Visi Sukses Bersama menggunakan metode sebagai berikut:

a. Rotasi Jabatan (Job Rotation)

PT Visi Sukses Bersama melakukan pemindahan tugas karyawan lama dari satu bagian ke bagian lain untuk menyesuaikan dengan pendidikan dan keahlian karyawan. Rotasi jabatan akan menjadi sangat penting karena dapat mengurangi rasa jenuh karyawan terhadap satu pekerjaan yang sama dan terus menerus. Dengan rotasi jabatan ini maka karyawan akan memperoleh pengalaman kerja. Di tempat kerjanya yang baru, seorang karyawan akan dapat mengasah kemampuannya dalam bekerja. Di PT Visi Sukses Bersama ada saling keterkaitan antara manajer dan para staffnya. Keduanya dapat saling menilai demi kemajuan perusahaan. Misalnya seorang karyawan yang berada di posisi promosi dipindahkan ke bagian umum karena perusahaan menganggap karyawan tersebut lebih cocok di posisi tersebut, sehingga kinerja karyawan tersebut dapat maksimal.

b. Latihan Instruksi Pekerjaan

Latihan instruksi pekerjaan di PT Visi Sukses Bersama dilakukan dengan cara penugasan kepada karyawan baru untuk menangani pekerjaan tertentu. Dengan cara ini, seorang karyawan diperintahkan melaksanakan tugas yang belum pernah atau sudah pernah dia lakukan yang berhubungan dengan pekerjaannya. Melalui latihan instruksi pekerjaan atasan dapat mengetahui seberapa kemampuan karyawan tersebut. Cara ini biasanya untuk karyawan yang baru atau karyawan lama tetapi menempati posisi yang baru.

c. Magang

PT Visi Sukses Bersama melakukan program magang agar karyawan akan terlatih untuk menghadapi masalah-masalah baru yang mungkin muncul dan dapat mengerjakan setiap tugas nya dengan baik dan benar. Jadi program magang ini dapat dijadikan sarana uji coba sebelum karyawan ditempatkan pada posisi yang baru.

d. Pembekalan (Coaching)

Pada PT Visi Sukses Bersama pembekalan dilakukan oleh manajer kepada karyawan yang baru. Karyawan tersebut akan mendapatkan perhatian lebih dari manajernya pada awawl-awal masa kerjanya. Karyawan dibimbing agar dapat bekerja dengan baik dan dapat memahami pekerjaannya. Dalam hal ini manajer memegang peranan penting dalam proses adaptasi dan kemampuan karyawan baru untuk bekerja sesuai dengan kebutuhan perusahaan. Sebagai contoh manajer keuangan membimbing karyawan yang baru bagai mana tugas-tugasnya dan bagaimana proses pengerjaannya.

5. Keputusan

Manager HRD akan memberikan keputusan. Jika diputuskan iya, maka karyawan tersebut layak disertakan dalam program pelatihan. Namun jika tidak disetujui, maka data karyawan akan dikembalikan ke Supervisor Pelatihan dan Pengembangan.

6. Pelaksanaan Pelatihan dan Pengembangan Selanjutnya proses yang keempat merupakan rangkaian kegiatan pelaksanaan program pelatihan dan pengembangan yang terdiri dari jadwal Pelaksanaan Pelatihan dan pengembangan karyawan.

Berikut ini tabel yang berisi data peserta pelatihan dan pengembangan di PT Visi Sukses Bersama Periode Agustus-November 2017

Tabel 1. Peserta Pelatihan dan Pengembangan Karyawan Periode AgustusNovember 2017

\begin{tabular}{cccc}
\hline No & Nama & Status & Kepesertaan \\
\hline 1 & A & Tetap & Rotasi \\
\hline 2 & B & Tetap & Rotasi \\
\hline 3 & C & Tetap & Rotasi \\
\hline 4 & D & Baru & Pelatihan \\
\hline 5 & E & Baru & Pelatihan \\
\hline 6 & F & Baru & Pelatihan \\
\hline 7 & G & Baru & Pelatihan \\
\hline 8 & H & Baru & Pelatihan \\
\hline 9 & I & Baru & Pelatihan \\
\hline 10 & J & Baru & Pelatihan \\
\hline 11 & K & Baru & Pelatihan \\
\hline 12 & L & Baru & Pelatihan \\
\hline 13 & M & Baru & Pelatihan \\
\hline Sumber: PT Visi Sukses Bersama &
\end{tabular}

7. Evaluasi Pelatihan dan Pengembangan

Proses Pelatihan yang terakhir adalah evaluasi yaitu menilai program-program yang telah diadakan oleh PT Visi Sukses Bersama apakah target-target yang telah ditetapkan tercapai atau tidak.

8. Selesai

Hal terpenting setelah pelaksanaan, adalah program evaluasi. Dalam hal ini, evaluasi pelatihan dan 
pengembangan pada PT Visi Sukses Bersama, dilakukan dengan 2 (dua) cara, yaitu:

1. Untuk menilai program-program yang telah diadakan oleh PT Visi Sukses Bersama, maka diadakan evaluasi mengenai pelatihan dan pengembangan, apakah target-target yang telah ditetapkan tercapai atau tidak. Pada PT Visi Sukses Bersama evaluasi diadakan secara berjalan. maksudnya, penilaian dilakukan setelah karyawan mengikuti pelatihan dan pengembangan.

Karyawan tersebut harus memberikan laporan secara tertulis kepada perusahaan. Laporan berisi kinerja karyawan tersebut yang berkaitan dengan pengetahuan yang telah didapat dari pelatihan dan pengembangan, laporan yang diterima perusahaan dari karyawan yang mengikuti pelatihan dan pengembangan akan terus diperiksa untuk mengetahui perkembangan kemampuan karyawan tersebut. Bagi karyawan yang mengalami peningkatan kemampuan dan mampu mengajarkannya pada karyawan lain akan mendapat penghargaan dari perusahaan, baik berupa bonus maupun promosi jabatan.

2. Pada bulan keempat setelah melaksanakan pelatihan dan pengembangan, maka karyawan akan dievaluasi dalam melakukan pekerjaan. Pemantauan dilakukan tanpa sepengetahuan karyawan, apabila karyawan yang menunjukkan kemajuan, maka karyawan tersebut akan ditetapkan menjadi karyawan kontrak selama 1 (tahun) lamanya, dengan mentanda tangani surat perjanjian kerja. Dan apabila pelaksanaan pelatihan dan pengembangan telah selesai dalam waktu lebih dari 3 (tiga) bulan telah dilakukan evaluasi, karyawan tidak menunjukkan hasil kinerja yang kurang baik dengan pelatihan dan pengembangan yang diberikan, maka Supervisor Seleksi akan memberitahukan kepada Manajer HRD untuk membuat keputusan yang sesuai dengan isi surat perjanjian kerja, selanjutnya pihak Manajer HRD akan membuat Surat Pemutusan Hubungan Kerja (PHK) untuk dapat ditanda tangani langsung oleh karyawan.

Model evaluasi Kirkpatrick merupakan model evaluasi pelatihan yang dikembangkan pertama kali oleh Donald L. Kirkpatrick telah dikembangkan di PT Visi Sukses Bersama dengan menggunakan empat level dalam mengkategorikan hasil-hasil pelatihan. Empat level tersebut adalah level reaksi, pembelajaran, perilaku dan hasil.

Keempat level dapat dirinci sebagai berikut:

1. Reaksi dilakukan untuk mengukur tingkat reaksi yang didisain agar mengetahui opini dari para peserta pelatihan mengenai program pelatihan.
2. Pembelajaran mengetahui sejauh mana daya serap peserta program pelatihan pada materi pelatihan yang telah diberikan.

3. Perilaku diharapkan setelah mengikuti pelatihan terjadi perubahan tingkah laku peserta (karyawan) dalam melakukan pekerjaan.

4. Hasil untuk menguji dampak pelatihan terhadap kelompok kerja atau organisasi secara keseluruhan.

Tabel 2. Hasil Evaluasi Pelatihan dengan Model Kirkpatrick

\begin{tabular}{|c|c|c|}
\hline No & Level & Keterangan \\
\hline 1 & Reaksi & $\begin{array}{l}\text { Peserta pelatihan memberikan } \\
\text { reaksi sangat positif terhadap } \\
\text { materi, trainer dan metode } \\
\text { pelatihan }\end{array}$ \\
\hline 2 & Pembelajaran & $\begin{array}{l}\text { Karyawan mengikuti proses } \\
\text { pembelajaran dengan baik. Hal } \\
\text { ini dilihat dari antusiasme selama } \\
\text { pelaksanaan pelatihan }\end{array}$ \\
\hline 3 & Perilaku & $\begin{array}{l}\text { Peserta mampu menerapkan } 3 \mathrm{~S} \\
\text { setelah materi disampaikan }\end{array}$ \\
\hline 4 & Hasil & $\begin{array}{l}\text { Setelah pelatihan, peserta } \\
\text { membuat rencana tindak lanjut } \\
\text { (RTL) yang akan diaplikasikan di } \\
\text { tempat kerja }\end{array}$ \\
\hline
\end{tabular}

Pada program pelatihan dan pengembangan ini juga tidak terlepas dari kendala. Berikut kendala yang dihadapi PT Visi Sukses Bersama dalam pelaksanaan pelatihan dan pengembangan yang telah dilaksanakannya:

1. Kendala Pelatihan dan Pengembangan

Kendala yang muncul saat pelatihan dan pengembangan karyawan pada PT Visi Sukses Bersama berada pada sumber daya manusianya sendiri. Karyawan yang telah ditunjuk untuk mengikuti pelatihan diberi perintah secara langsung oleh perusahaan melalui surat resmi. Untuk karyawan yang berhalangan mengikuti harus memberikan keterangan yang jelas seperti sedang sakit, namun banyak karyawan yang tidak mengikuti pelatihan tanpa memberitahukan atau ijin pada pihak perusahaan sehingga peluang terbuang sia-sia. Karyawan masih beranggapan bahwa kegiatan tersebut tidak penting. Kurangnya kesadaran dan displin dari karyawan ini yang membuat beberapa kali pengadaan pelatihan kurang menuai hasil yang maksimal.

2. Cara mengatasi kendala Pelatihan dan Pengembangan

Setiap perusahaan pasti akan memiliki kendala yang dihadapi saat pelatihan tidak terkecuali pada PT Visi Sukses Bersama. Adapun cara mengatasi kendala yang dilakukan oleh PT Visi Sukses Bersama yaitu Digantikan oleh karyawan 
yang lain sesuai dengan diskripsi bidang kerjanya sehingga peluang tidak terbuang sia-sia.

\section{KESIMPULAN}

Berdasarkan hasil analisa data pembahasan yang telah disusun dalam penulisan laporan tugas akhir ini, maka penulis dapat menarik beberapa kesimpulan sebagai berikut:

1. Pelatihan dan pengembangan melalui tahapan penentuan kriteria, identifikasi kebutuhan, pemilihan metode, pembuatan keputusan, pelaksanaan dan evaluasi.

2. Evaluasi pelatihan dan pengembangan karyawan, dilakukan melalui penilaian selama pelaksanaan dan hasil kinerja karyawan, termasuk menggunakan evaluasi dengan model Kirkpatrick 4 level.

3. Kendala pelaksanaan pelatihan dan pengembangan, ada beberapa karyawan yang tidak bersedia hadir dalam kegiatan tersebut dengan berbagai alasan. Solusi dari kendala tersebut adalah menunjuk karyawan lain untuk menggantikan sebagai peserta.

Berdasarkan kesimpulan-kesimpulan di atas, maka pelaksanaan program pelatihan dan pengembangan karyawan di PT Visi Sukses Bersama telah terlaksana dengan baik, namun perlu adanya peningkatan yang lebih baik dalam sistem pemilihan karyawan yang akan mengikuti pelatihan dan pengembangan agar program ini mendapat hasil yang maksimal di semua bagian.

\section{REFERENSI}

Andayani, N. R., \& Makian, P. (2016). Pengaruh Pelatihan Kerja dan Motivasi Kerja terhadap Kinerja Karyawan Bagian PT. PCI Elektronik International (Studi pada Karyawan PT PCI Elektronik International). Jurnal Akuntansi, Ekonomi Dan Manajemen Bisnis, 4(1), 41-46. https://doi.org/10.1098/rsta.2015.0118

Hasibuan, S.P Malayu. (2016). Manajemen Sumber Daya Manusia. Jakarta: Yogyakarta: BPFE

Kurniawan, A. W. (2012). Pengaruh Kepemimpinan Dan Pengembangan Sumber Daya Manusia Terhadap Kepuasan Kerja, Motivasi Kerja, dan
Kinerja Karyawan Bank Sulselbar. Ekonomi Dan Keuangan, 16(4), 391-408.

Lolowang, M. G., Adolfina, \& Lumintang, G. (2016). Pengaruh Pelatihan dan Pengembangan Sumber Daya Manusia Terhadap Kinerja Karyawan Pada PT. Berlian Kharisma Pasifik. Emba, 4(2), 177-186.

Marwansyah. (2016). Manajemen Sumber Daya Manusia. Bandung: CV. Alfabeta.

Massie, R., Tewal, B., \& Sendow, G. (2015). Pengaruh Perencanaan Karir, Pelatihan dan Pengembangan Karir Terhadap Kinerja Pegawai Pada Museum Negeri Provinsi Sulawesi Utara, 15(05), 635-645.

Onibala, N. R., Tewal, B., \& Sendow, G. M. (2017). Pengaruh Pendidikan, Pelatihan dan Pengembangan Karir Terhadap Kinerja Pegawai Pada Kantor Pelayanan Kekayaan Negara dan Lelang Manado. Emba, 5(2), 27902798.

Simamora, Henry. (2015). Manajemen Sumber Daya Manusia. Yogyakarta: STIE-YKPN

Wicaksono, Y. S. (2016). Pengaruh Pelatihan dan Pengembangan Sumber Daya Manusia Dalam Rangka Meningkatkan Semangat Kerja dan Kinerja Karyawan (Studi di SKM Unit V PT. Gudang Garam, Tbk Kediri). Jurnal Bisnis Dan Manajemen, 3(1), 31-39.

\section{PROFIL PENULIS}

R. Ati Haryati, SH, MH. merampungkan studi S1 dan S2 Hukum di Universitas Jayabaya Jakarta. Selain berkarir di dunia pendidikan di ASM BSI Jakarta, juga menekuni bidang hukum dan terlibat aktif di beberapa organisasi sosial yang berkaitan dengan bidang hukum. Adapun mata kuliah yang diampu antara lain: KNBI dasar, KNBI lanjut, Hukum dan Etika Bisnis. 